Article

\title{
Saharan Hot and Dry Sirocco Winds Drive Extreme Fire Events in Mediterranean Tunisia (North Africa)
}

\author{
Chiraz Belhadj-Khedher ${ }^{1,2}\left(\mathbb{D}\right.$, Taoufik El-Melki ${ }^{1}$ and Florent Mouillot ${ }^{3, *(\mathbb{C}}$ \\ 1 UR Geomatique \& Geosystèmes, Campus universitaire, Université Manouba, BP95, 2010 Manouba, Tunisia; \\ Chiraz_belhadj@yahoo.fr (C.B.-K.); lmlkitfik@gmail.com (T.E.-M.) \\ 2 Faculté des Sciences Humaines et Sociales de Tunis, 94 Bd du 9 Avril 1938, 1007 Tunis, Tunisia \\ 3 UMR CEFE, Univ. Montpellier, CNRS, EPHE, IRD, Univ. Paul Valery Montpellier 3, 1919 route de Mende, \\ 34293 Montpellier CEDEX 5, France \\ * Correspondence: florent.mouillot@ird.fr; Tel.: +33-467613353
}

Received: 30 April 2020; Accepted: 1 June 2020; Published: 3 June 2020

\begin{abstract}
With hot and dry summers, the Mediterranean basin is affected by recurrent fires. While drought is the major driver of the seasonal and inter-annual fire distribution in its northern and mildest climate conditions, some extreme fire events are also linked to extreme winds or heat waves. The southern part of the Mediterranean basin is located at the driest range of the Mediterranean bioclimate and is influenced by Saharan atmospheric circulations, leading to extreme hot and dry episodes, called Sirocco, and potentially acting as a major contributor to fire hazard. The recently created fire database for Tunisia was used to investigate the \pm 10 -day pre- and post-fire timeframe of daily weather conditions associated with fire events over the 1985-2006 period. Positive anomalies in minimum and maximum temperatures, negative anomalies in air relative humidity, and a preferential south-eastern wind during fire events were identified, which were characteristic of Sirocco winds. $+7^{\circ} \mathrm{C}$ anomalies in air temperature and $-30 \%$ in relative air humidity were the critical thresholds for the most extreme fire conditions. In addition, meteorological anomalies started two days before fire events and lasted for three days after for large fires $>400$ ha, which suggests that the duration of the Sirocco event is linked with fire duration and final fire size. Lastly, the yearly number of intense Sirocco events better explained the inter-annual variability of burned area over the 1950-2006 period than summer drought based on Standardized Precipitation Evaporation Index (SPEI) indices.
\end{abstract}

Keywords: fire; climatology; Mediterranean basin; extreme events; Sirocco

\section{Introduction}

With hot and dry summers, the Mediterranean basin is affected by recurrent fires shaping landscapes [1,2] and species functional traits [3]. Because of a significant climate gradient from north to south and following the fire varying constraint hypothesis [4], fire hazard in this region is driven by both fuel availability at the southern part of the drought gradient, and the length of the drought period defined by seasonal fuel moisture content at the northern part [5]. This latitudinal gradient follows a constraint gradient, switching from moisture limitation to fuel limitation [6]. In non-fuel-limited ecosystems, recent studies illustrate the importance of summer drought on the inter-annual variation of burned area across the basin $[7,8]$ and its value in fire hazard predictions [9]. However, the strength of the yearly drought/burned area relationship decreases going southward [10], which suggests the potential for spatial heterogeneity in 
the relative contribution of other keystone climate variables over the Mediterranean basin, as observed across continents within similar biomes [11] or between ecoregions [12]. Recent studies illustrate the significant influence of air temperature on fire activity in Spain [13], where summer drought is recurrent, so that inter-annual variability of heat wave frequency is more important than inter-annual variability of drought length. Most Mediterranean-scale projections of fire danger rely on the Canadian fire weather index (FWI) integrating drought, daily temperature, air humidity, and wind information [14]. More recently, fire events in the Mediterranean basin have been related to general circulation patterns and subsequent weather anomalies around these fire events [15]. Various fire weather types (named wind-, drought-, or heat-driven fire weathers) could then be identified to better characterize the heterogeneity of fire weather types in local fire regimes, and how the relative frequency of these weather types might change over long time-scales and from one year to the other [16]. These analyses were based on daily anomalies of keystone weather variables as temperature, relative air humidity, and wind speed to capture their temporal variability before and during fire events, and they could bring a more detailed understanding of the various weather conditions leading to large fires. We hypothesize that a particularly high frequency of heat waves would impact fire occurrence at the southern rim of the Mediterranean basin based on the identification of these various fire weather types potentially occurring in the Mediterranean basin, and the identified weaknesses on the applicability of a unique fire weather index. Indeed, the northward Sirocco wind is the most well-described climate phenomenon affecting air quality, health, and environment in this region, resulting from a depression centered in central Mediterranean, with northward winds bringing hot and dry air from Sahara [17]. Fires affect forested ecosystems that border arid areas worldwide during these extreme weather episodes and atmospheric circulation schemes blowing abnormally hot and dry winds for several consecutive days. The most documented phenomenon is the Santa Ana event in California with hot and dry winds blowing from the continental desert of Nevada toward the Californian coast and leading to the major fire events in this region [18]. The southern rim of the Mediterranean basin has been little investigated due to the lack of fire data, but it could highly contribute to a full understanding of fire hazard control along the whole Mediterranean gradient. Our study is based on the hypothesis that a process similar to Californian Santa Ana weather conditions, i.e., a shift in wind direction generating short-term weather anomalies, would be an indicator of Sirocco events [19]. The recently published quality-checked fire database in Tunisia for the 1985-2010 period [20] was used (i) to investigate the pre- and post-fire daily weather related to fire size occurrence over a $+/-10$-day timeframe and (ii) to test how southern winds from Sahara are associated with meteorological anomalies during fire events. The link between the intensity of weather anomalies and fire size was then tested in order to build a yearly burned area model based on the number of Sirocco events that was compared with a drought-based model.

\section{Material and Methods}

\subsection{Study Area}

The study area covers the northern part of the Tunisian national territory where forest ecosystems occur in the humid Mediterranean and semi-arid bioclimates [20]. The region is mountainous, with elevation that ranges from $0 \mathrm{~m}$ on the coast to $1235 \mathrm{~m}$ at Mount Chaambi (Atlas Mountains range) (Figure 1). The regional climate is Mediterranean, with precipitation mostly being distributed in autumn, winter, and spring, while summers are dry, with a strong north/south gradient getting drier upon reaching the Sahara desert in the south of the country. Tunisia covers a total area of $165,000 \mathrm{~km}^{2}$, with only $9416 \mathrm{~km}^{2}$ of forests and shrublands. Quercus suber L. covers 70,000 ha on the northern part of the country where mean annual precipitation is $800 \mathrm{~mm}$, varying between $700 \mathrm{~mm}$ and $1500 \mathrm{~mm}$, and mean temperature is $16{ }^{\circ} \mathrm{C}$ [21]. Pinus halepensis Miller covers 361,000 ha in the central part of the country where mean annual precipitation is $400 \mathrm{~mm}$ [22]. Mediterranean shrublands cover 328,000 ha and they are composed of Arbutus unedo L., 
Erica arborea L. Cistus spp. L, Phyllirea latifolia L., and Pistacia lentiscus L. on the northern coastal part and Rosmarinus officinalis L., Cistus spp. L., and Lavendula spp. L. in the central part [23].

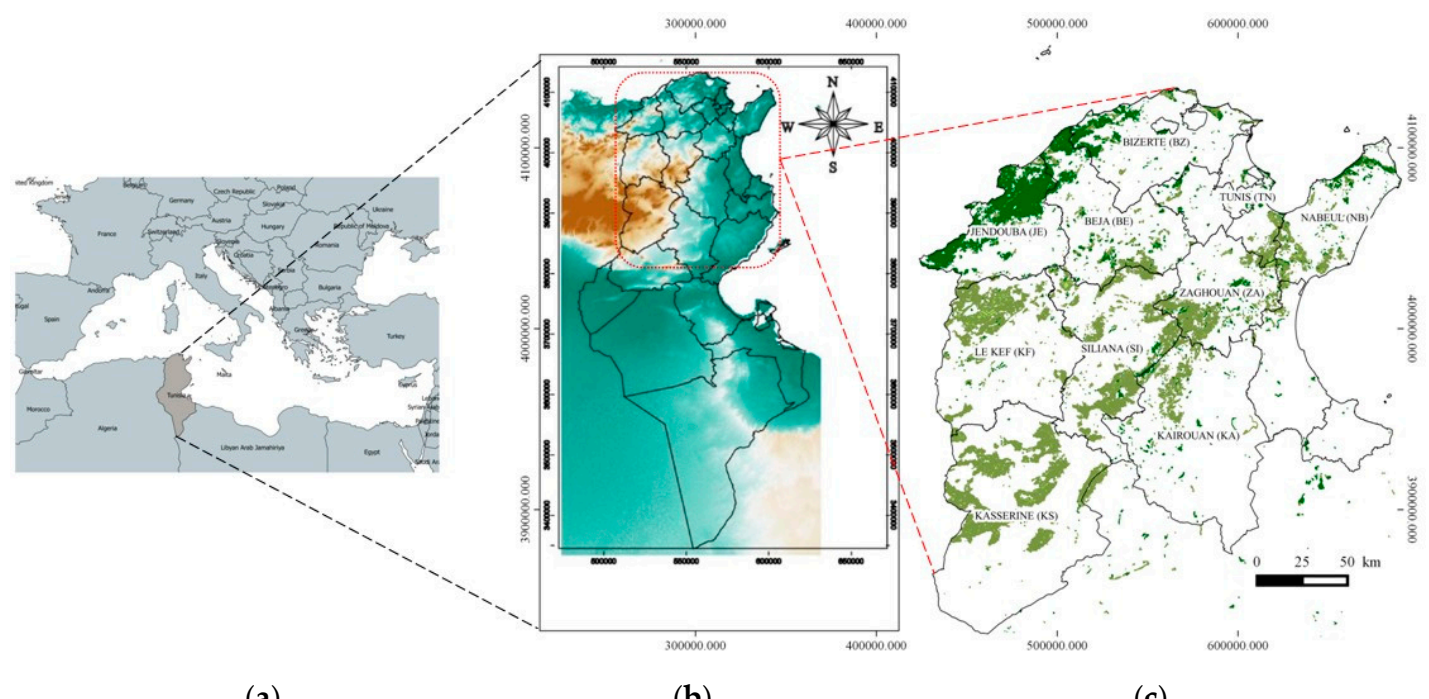

(a)

(b)

(c)

Figure 1. Location of Tunisia within the Mediterranean basin (a); with the map of altitudes (b); and, administrative units overlayed with forest/shrubland distribution (c).

\subsection{Fire Data}

Daily fire data were collected from the Tunisian Forest services, starting in 1985 (Source Direction Générale des Forêts, Tunisie), and being checked and corrected with remote sensing [20]. For missing fires in the national database that were captured with Landsat images, burn date was determined by the MCD14ML global hotspot database from the MODIS sensor [24]. The exact burn date of these missing fires could not be identified due to the lack of MCD14ML data before 2000, and they were removed from the analysis. Each fire is defined by its ignition date, end date of the fire (so we could derive fire duration), location, burned area, and vegetation type. For this analysis, wildland fires (affecting forests and shrublands) were selected (so that agricultural burnings were removed) and then classified into small fires (>1 ha), medium (>100 h), and large fires (>400 ha), with 968, 94, and 23 fires, respectively, in each fire class.

\subsection{Climate Data}

Daily climate data from the Tunis meteorological station (latitude $=36.75^{\circ} \mathrm{N}$, longitude $=10.25^{\circ} \mathrm{E}$ ), being representative of the general circulation of the country, were provided by INM (Institut National de la Météorologie, Tunis) for the period 1950-2006. The following variables were used: maximum temperature $\mathrm{T}_{\max }\left({ }^{\circ} \mathrm{C}\right)$, minimum temperature $\mathrm{T}_{\min }\left({ }^{\circ} \mathrm{C}\right)$, air relative humidity $\mathrm{HR}(\%)$, wind speed WS $\left(\mathrm{m} \cdot \mathrm{s}^{-1}\right)$, and wind direction WDIR (in degrees of deviance from North). Climate reanalysis can be used as an alternative source of data [16], but our analysis covered the period back to 1950 with this long time series on temperature, and tested whether local weather data could be used for future early alert systems.

From these climate variables and daily precipitation, a drought index (DI) was computed from the drought code (DC) component of the fire weather index (FWI) [25]. This index has been developed for Canadian forests as an index of litter moisture, and further used globally and in the Mediterranean basin as a proxy for plant fuel moisture [26]. DI is 0 for the driest conditions and it reaches a maximum value of 1 when the soil water content is at field capacity. 
As a global drought index reference, and for comparison with other studies, the Standardized Precipitation Evaporation Index (SPEI) was downloaded from the global SPEI database [27] in order to test for the relative importance of summer drought on the inter-annual burned area. SPEIs for the month of September (end of the dry season) and for the preceding timeframes of one to seven months were extracted for the $0.25^{\circ}$ grid cell of the Tunis station.

\subsection{Statistical Analysis}

For each fire event, daily weather conditions for all climate variables were extracted from 10 days before to 10 days after the fire. Daily weather conditions over the same timeframe were also extracted for each day over the fire season from July to September. The mean values and uncertainties for each climate variable were plotted on a temporal scale. The daily uncertainty was assessed through a bootstrapped subsampling with 1000 replicates due to a non-normal distribution of climate variables (Shapiro-Wilk $\mathrm{W}$ test, with a significance threshold fixed at 0.05 , shapiro.test function in 'stats' Rcran package [28]). For each replicate, the mean value of climate variables on 10 events randomly sampled within the whole dataset was calculated. The upper and lower confidence levels were calculated with the 'quantile' function, respectively, at 0.9 and 0.1 significance threshold applied to the 1000 means obtained for each replicate.

From this analysis, the duration of weather anomaly was derived as the number of days when $\mathrm{T}_{\max }$ was above the upper confidence interval of the mean $\mathrm{T}_{\max }$ over the summer season for each fire size class. Plots of fire size (log10 transformed) as a function of the duration of the fire (as registered in the forest service database) and the duration of the weather anomaly were performed with the 'ggplot2' R cran package. A log10 model fitting was performed with a locally weighted least square regression 'loess' option in the 'geom_smooth' function with confidence interval being fixed at 0.95 .

As a final step, the correlations between yearly burned area and summer drought or number of weather anomaly events (that were attributed to Sirocco meteorological phenomenon) during the fire season were evaluated. Summer drought was based on SPEI_september indices. The number of Sirocco events during the fire season was based on either a direct temperature anomaly as a difference with the mean summer $\mathrm{T}_{\max }$ value of $33{ }^{\circ} \mathrm{C}$ (Nsir_Tmax) or the abrupt temporal variation of $\mathrm{T}_{\max }$ between the day $=i$ and day $=i-3$ (Nsir_Tdiff). The effects of drought and Sirocco intensities were evaluated, respectively, from a one-month to a seven-month timeframe, and a $+1{ }^{\circ} \mathrm{C}$ to a $+7{ }^{\circ} \mathrm{C} \mathrm{T}_{\max }$ anomaly. Correlations between yearly burned area and meteorological indices were performed with the Pearson test and the significance level was determined with a Monte Carlo randomization on 1000 replicates using the 'meancorr' function of the 'synchrony' $\mathrm{R}$ cran package [29]. The Monte Carlo randomizations were performed by independently shuffling the columns of matrix, thus destroying the potential temporal autocorrelation of time series. To capture only the qualitative synchrony of high and low burned area extremes (and not the burned area/weather relationship) with climate indices, the proportion of local minima/maxima common to both time series was also computed. The upper and lower peaks in each time series were identified when the derivative values changed signs. The significance level was estimated with the same Monte Carlo randomization as the correlation, by using the 'peaks' function of the 'synchrony' $\mathrm{R}$ cran package [29].

A linear model was finally applied to establish the relationship between annual burned area and annual climate indices of drought or the number Sirocco events (NSir_Tmax and NSir_Tdiff) using the ' $d y n l m$ ' $\mathrm{R}$ cran function designed for time series regression. The modeled burned area was then simulated using the 'predict' function that was applied to the $\mathrm{T}_{\max }$ time series over the 1950-2006 period. Before analysis, the annual burned area and the number of Sirocco events were log 10 transformed due to a non-normal distribution ( $p$ value $<0.05$, Shapiro-Wilk test). The SPEI indices were normally distributed ( $p$ value $>0.05$, Shapiro-Wilk test) and were kept non-transformed. 
Wind roses for the whole summer season and for two fire size classes (fire size $>1$ ha, and $>400$ ha) were built for the climate variables $\mathrm{T}_{\max }$, wind speed $\mathrm{WS}$, and air relative humidity $\mathrm{HR}$, in order to illustrate the preferential directions of fire events and their associated weather conditions. Wind roses were built with the 'ggplot2' R cran Package.

\section{Results}

\subsection{Time-Lagged Fire/Weather Analysis}

Figure 2 represents the mean and confidence interval for each climate variable during the 10 days before $(-10)$ and after $(+10)$ fire events and for the three fire size classes as compared to the whole fire season.

For minimum temperature $\mathrm{T}_{\min }$ (Figure $2 \mathrm{a}$ ), the mean value during the fire season (with or without fires) was $21^{\circ} \mathrm{C}\left( \pm 1^{\circ} \mathrm{C}\right)$. For small fires $(>1 \mathrm{ha})$, a positive non-significant anomaly of $22^{\circ} \mathrm{C}\left( \pm 1^{\circ} \mathrm{C}\right)$ one day before the fire event was observed then reaching $+23{ }^{\circ} \mathrm{C}\left( \pm 1^{\circ} \mathrm{C}\right)$ for fires $>100$ ha and $24{ }^{\circ} \mathrm{C}\left( \pm 1.5^{\circ} \mathrm{C}\right)$ for fires $>400$ ha. This anomaly was only observed for day $(-1)$ for small fires, from day -1 to day +1 for medium fires $>100$ ha, and from day -1 to day +3 for large fires $>400$ ha.

For maximum temperature $\mathrm{T}_{\max }$ (Figure $2 \mathrm{~b}$ ), the mean value during the fire season was $33{ }^{\circ} \mathrm{C}$ $\left( \pm 1^{\circ} \mathrm{C}\right)$. For small fires, the positive anomaly to $34^{\circ} \mathrm{C}\left( \pm 1^{\circ} \mathrm{C}\right)$ during fire events was not significant, reaching significant differences of $37.5^{\circ}\left( \pm 1^{\circ} \mathrm{C}\right)$ and $38^{\circ} \mathrm{C}\left( \pm 2{ }^{\circ} \mathrm{C}\right)$ for medium and large fires, respectively. The anomaly was observed from day -1 to day +1 for small fires, from day -2 to day +3 for medium fires, and from day -2 to day +5 for large fires, respectively, leading to anomaly events prolonged over three, six, and eight days.

These positive temperature anomalies were associated with negative air humidity (HR) anomalies (Figure 2c). The mean HR over the summer was $62 \%$ ( $\pm 3 \%)$. For small fires, a non-significant negative anomaly down to $60 \%( \pm 2.5 \%)$ was observed for day -1 and during the fire event, significantly decreasing to $55 \%( \pm 3 \%)$ and $52 \%( \pm 2 \%)$ during medium and large fire events. A HR negative anomaly occurred from day -2 until day +1 for medium fires, and from day -3 until day +4 for large fires, respectively, lasting two, four, and eight days.

During these dry and hot events, wind speed was slightly higher than the mean summer value (Figure 2d). Wind speed over the summer season was $8.5( \pm 1) \mathrm{m} \cdot \mathrm{s}^{-1}$, not being significantly different during small and medium fires, but slightly significantly higher, up to $10( \pm 1) \mathrm{m} \cdot \mathrm{s}^{-1}$, from day -1 to day +3 for large fires.

All of these climate variable anomalies were associated with a significant change in wind direction (Figure 2e). The dominant incoming wind direction in the region was $\mathrm{NW}\left(245^{\circ} \pm 10^{\circ}\right)$. This wind direction progressively deviated to south according to fire size, reaching $235^{\circ}$ for small fires, $205^{\circ}$ (SW) for medium fires, and $175^{\circ}$ (SSE) for large fires. This wind direction anomaly started during the fire event and lasted until day +4 for large fires, and until day +3 for medium fires.

The drought conditions during fire events were longer lasting and did not show any specific temporal anomalies during or around the fire events (Figure 2f). The mean DI during the fire season was $0.4( \pm 0.05)$, decreasing to 0.35 for small and medium fires and to 0.3 for large fires, suggesting slightly dryer conditions around fire events than during the rest of the dry season. 


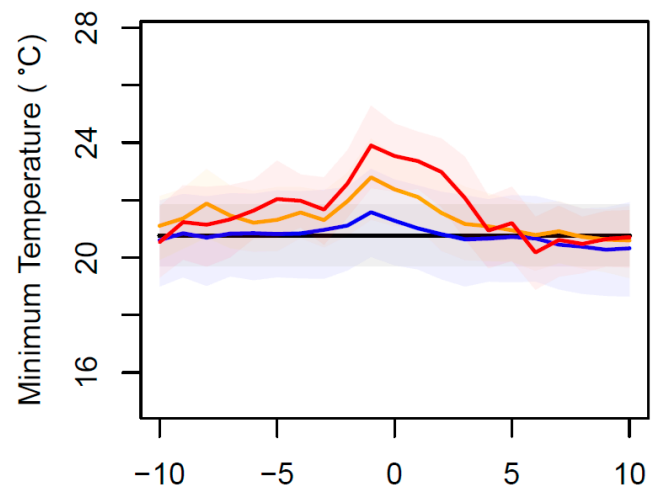

(a)

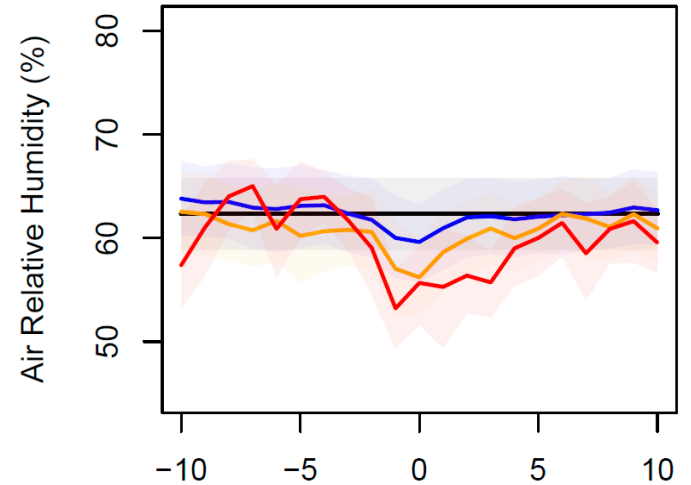

(c)

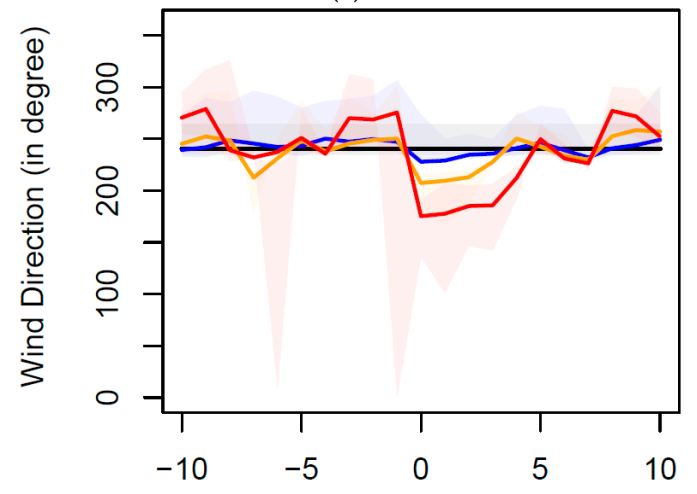

Number of days before/after fires

(e)

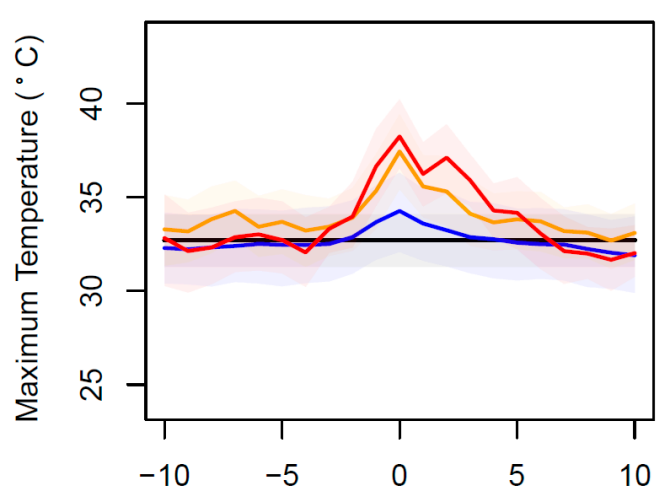

(b)

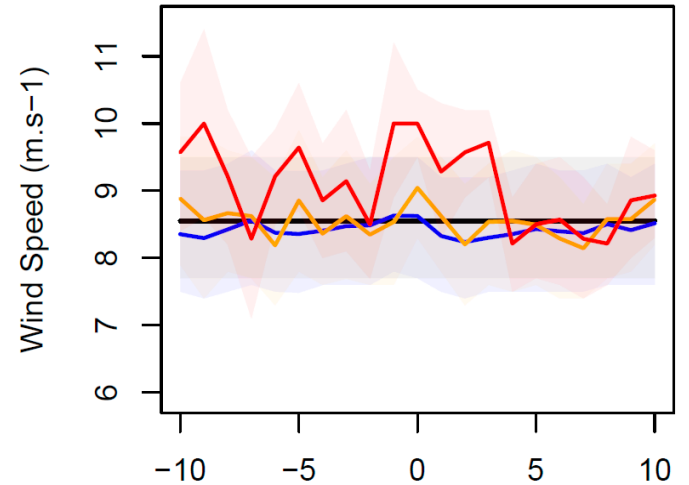

(d)

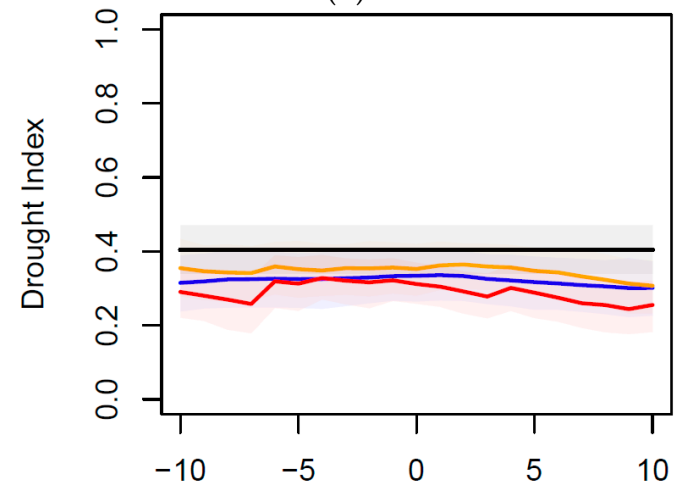

Number of days before/after fires

(f)

Figure 2. Mean daily weather values from 10 days before to 10 days after fire events for fire size classes $>1$ ha (blue), >100 ha (yellow), >400 ha (red), and all days during the July-August fire season (black), for daily climate variables of (a) minimum temperature $\left(\mathrm{T}_{\min }\right.$ in $\left.{ }^{\circ} \mathrm{C}\right),(\mathbf{b})$ maximum temperature $\left(\mathrm{T}_{\max }\right.$ in ${ }^{\circ} \mathrm{C}$ ), (c) relative air humidity (HR in \%) (d) wind speed (WS in $\mathrm{m} \cdot \mathrm{s}^{-1}$ ), (e) wind direction (WDIR in degree deviation from North), and (f) drought index (DI) varying from 0 (completely dry) to 1 (full moisture) soil water conditions. Colored shaded areas correspond to the 90\% confidence interval obtained from 1000 bootstrapped subsamples.

\subsection{Fire Weather Frequency and Fire Duration}

Wind roses of maximum air temperature $\left(\mathrm{T}_{\max }\right)$, wind speed (WS), and air relative humidity (HR) are presented in Figure 3 for all days during the summer season, and during small and large fires, to 
better understand the frequency distribution of fire weather during fire events. The dominant wind directions in the area were NW $\left(285-315^{\circ}\right)$, followed by NNE $\left(15-45^{\circ}\right)$ and ESE $\left(105-135^{\circ}\right)$. NW winds were usually cooler with $33 \%$ of days with $\mathrm{T}_{\max }<20^{\circ} \mathrm{C}$, while ESE winds were warmer with $50 \%$ of days $>30{ }^{\circ} \mathrm{C}$ with some extremes $>40{ }^{\circ} \mathrm{C}$. Regarding HR, all directions were quite similar, with $15 \%$ of days reaching HR $>80 \%, 40 \%$ of days $80 \%>$ HR $>70 \%, 40 \%$ of days $70 \%>$ HR $>60 \%$, and $5 \%$ with $\mathrm{HR}<60 \%$. Wind speed was more related to wind direction. The fastest winds came from the NW direction with $50 \%$ of days reaching $>10 \mathrm{~m} \cdot \mathrm{s}^{-1}$, while $70 \%$ of days with wind direction NE to SE experienced wind speed $<10 \mathrm{~m} \cdot \mathrm{s}^{-1}$. We could then differentiate NW winds as cooler and faster as opposed to SE winds as hotter and slower in Tunisia during the fire season.

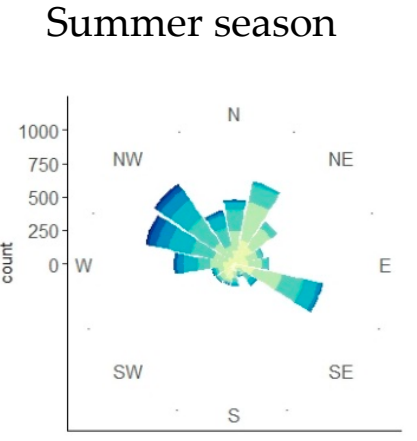

(a)

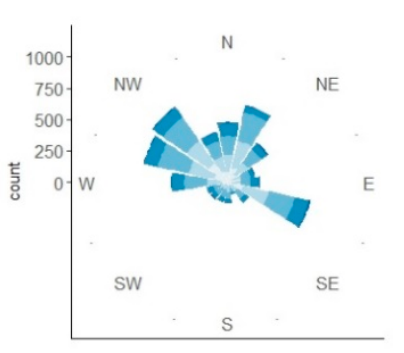

(d)

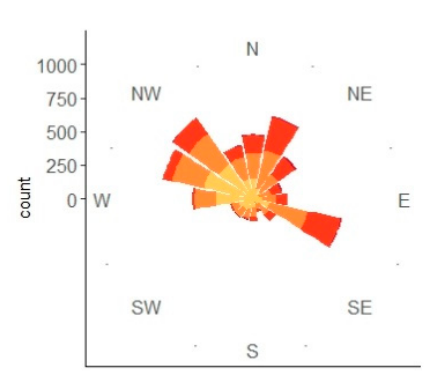

$(\mathrm{g})$
Fires $>1$ ha

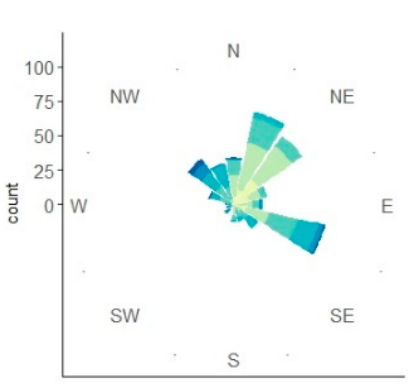

(b)

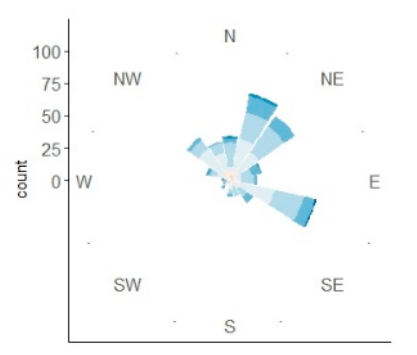

(e)

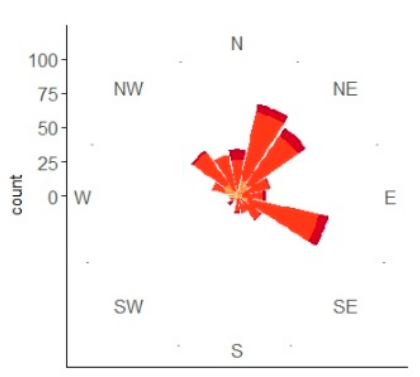

(h)
Fires $>400$ ha

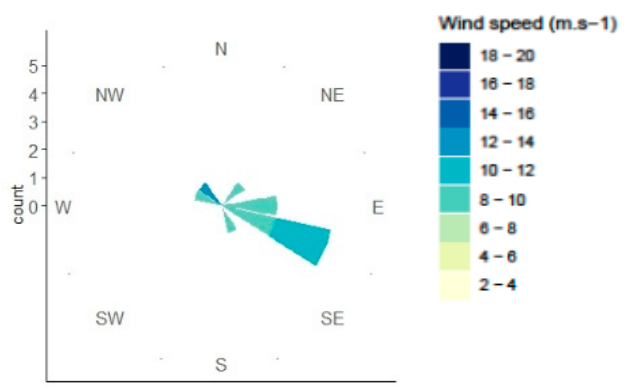

(c)

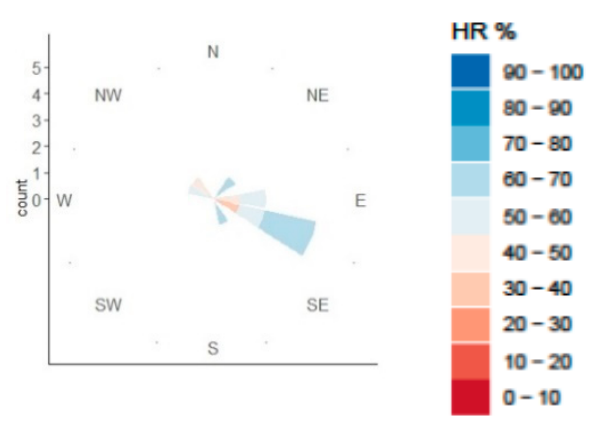

$(\mathbf{f})$

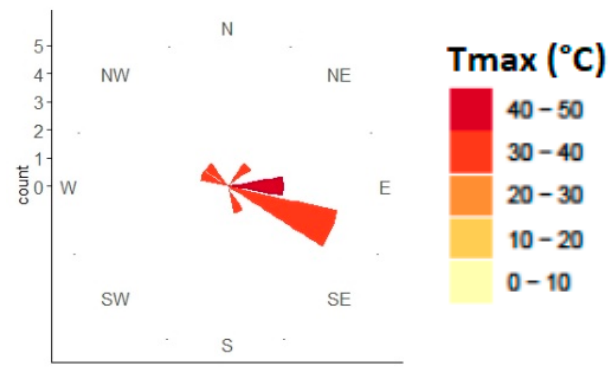

(i)

Figure 3. Wind roses representing the frequency distribution of wind directions during the fire season $(\mathbf{a}, \mathbf{d}, \mathbf{g})$, small fires $(\mathbf{b}, \mathbf{e}, \mathbf{h})$, and large fires $(\mathbf{c}, \mathbf{f}, \mathbf{i})$, and the frequency of associated weather variables values for wind speed (WS in $\left.\mathrm{m} \cdot \mathrm{s}^{-1}\right)(\mathbf{a}, \mathbf{b}, \mathbf{c})$, air relative humidity (HR in \%) $(\mathbf{d}, \mathbf{e}, \mathbf{f})$, and maximum air temperature $\left(\mathrm{T}_{\max }\right.$ in $\left.{ }^{\circ} \mathrm{C}\right)(\mathbf{g}, \mathbf{h}, \mathbf{i})$ in each wind direction. 
For small-fire days ( $>1$ ha), the frequency of NW winds substantially decreased, so that NNE and ESE winds became dominant, with $\mathrm{T}_{\max }$ mostly $>30{ }^{\circ} \mathrm{C}$ and $\mathrm{HR}<80 \%$. Wind speed was faster in the ESE direction $\left(70 \%\right.$ of events $\left.>8 \mathrm{~m} \cdot \mathrm{s}^{-1}\right)$ than NNE $\left(80 \%\right.$ of events $\left.<8 \mathrm{~m} \cdot \mathrm{s}^{-1}\right)$. This result suggested that NW winds were less fire-prone as a consequence of cooler temperatures, even under faster wind speeds, and fires in Tunisia were mostly driven by warmer air temperature events.

Large fire events occurred almost only $(75 \%)$ during $\mathrm{E}$ to $\mathrm{SE}$ wind directions. $\mathrm{T}_{\max }$ was always $>30{ }^{\circ} \mathrm{C}$ with $25 \%$ of experiencing $\mathrm{T}_{\max }>40{ }^{\circ} \mathrm{C}$. Around $50 \%$ of days had $\mathrm{HR}<60 \%$, with the driest days $(\mathrm{HR}<50 \%)$ occurring with ESE wind direction. Wind speed remained mild between 8 and $12 \mathrm{~m} \cdot \mathrm{s}^{-1}$.

In turn, this analysis illustrated how a selective fraction of weather conditions were associated with fire events in Tunisia. It also confirmed the occurrence of ESE hot and dry winds in $75 \%$ of large fire events, complementing the mean fire/weather analysis previously performed, and characterizing the combination of weather anomalies occurring during Sirocco events.

\subsection{Fire Size and Sirocco Duration}

Figure 4 represents fire size ( $\mathrm{Y}$ axis, $\log 10$ scale) as a function of fire duration in days. The two variables were significantly correlated $\left(R^{2}=0.62\right)$, indicating that the final fire size depends on the duration of the fire. Particularly, fires smaller than 100 ha lasted for one or two days, while fires larger than 100 ha lasted from three to 12 days with a slight increase after that threshold. Plots of fire size as a function of Sirocco duration obtained from Figure $2 \mathrm{~b}$ showed a similar relationship, with short Sirocco events (zero to three days) leading to small fires, and longer Sirocco events leading to fires $>100$ ha. Sirocco duration, fire duration, and final fire size were all highly interrelated, which suggested that yearly Sirocco event frequency and duration might drive the annual burned area.

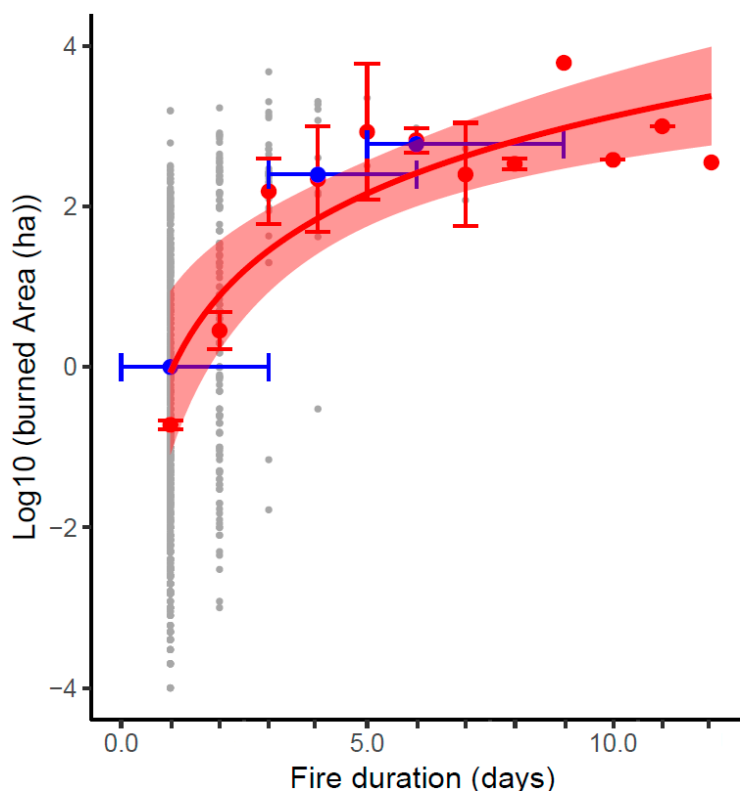

Figure 4. Relationship between fire size (Y-axis, Log10 scale in ha) and fire duration (X axis in days) over the 1985-2006 period in Tunisia (grey dots represent fire events and red dots the mean size for each duration with standard deviation intervals). The log10 regression fitted on mean values is also represented (Red line) with its $90 \%$ confidence interval (shaded red area). The duration of Sirocco events (in days) during fire size classes $>1$ ha, $>100$ ha and $>400$ ha is also represented (blue dots and 95\% confidence interval bars). 


\subsection{Temporal Fire Analysis and Modeling: 1950-2006}

Figure 5 illustrates the burned area simulated by the number of Sirocco days based on temperature anomalies (Nsir_Tmax) for the 1950-2006 period (blue line) based on the previous results relating fire size and Sirocco duration. The yearly burned area over the 1950-2006 period was simulated with $\mathrm{R}=0.44$ ( $p$ value $<0.001$ ) based on the number of Sirocco events defined by the highest maximum temperature anomaly $\left(+7^{\circ} \mathrm{C}\right)$. Correlation coefficients were lower, but still significant $(p$ values $<0.01)$ for anomalies of $+5{ }^{\circ} \mathrm{C}$ and $+6{ }^{\circ} \mathrm{C}$ (Table 1). The fraction of synchronized lower/upper extremes between burned area and Nsir_Tmax reached 0.45 for the highest temperature anomalies and decreased to 0.24 for the other significant correlations. However, the simulated burned area increased over time as a result of increasing temperatures over the region, leading to increasing model residuals in the recent years (Figure $5 \mathrm{c}$ ). As an alternative, the burned area was modeled by the number of Sirocco days based on the relative maximum temperature anomaly between the day of the fire event and three days before (Nsir_Tdiff). The burned area over the 1950-2006 period was simulated with a correlation coefficient $\mathrm{R}=0.40(p<0.01)$ for a $+7^{\circ} \mathrm{C}$ anomaly, a slightly lower performance than the previous index, but better capturing the recent decrease in burned area in the context of increasing average air temperature. The model residuals of the observed burned area in recent years were lower than the previous model (Figure $5 c$ ). The correlation coefficients decreased to $0.3(p<0.01)$ for temperatures anomalies ranging for $+4{ }^{\circ} \mathrm{C}$ to $+6{ }^{\circ} \mathrm{C}$. The fraction of synchronized lower/upper extremes between burned area and Nsir_Tdiff reached 0.38 for the highest temperature anomaly, and decreased to 0.24 for other significant correlations. In turn, the yearly burned area in Tunisia was mostly correlated to the number of extreme Sirocco events. Sirocco events, defined as hot and dry air from the south, were correlated to absolute daily maximum air temperature, but with a temporal trend more particularly related to temperature variations within a short period of time. Besides the significant effect of Sirocco events, none of the SPEI indices covering one to seven months before September were significantly correlated to annual burned area (Table 1 ). The fraction of synchronized low/upper extremes between burned area and SPEI was around 0.2 , with the highest and significant $(p<0.05)$ value of 0.36 reached for SPEI_3 corresponding to the July-September period.

Table 1. Correlation coefficients (and significance level ${ }^{1}$ ) and fraction of low/upper synchrony between yearly burnt area anomaly and fire hazard indices modelled from the number of Sirocco events based on temperature anomalies three days before and during fire events (Nsir_Tdiff), temperature anomaly above the $33{ }^{\circ} \mathrm{C}$ threshold (Nsir_Tmax) and the drought index Standardized Precipitation Evaporation Index (SPEI) (September). Levels indicate the temperature anomalies (in ${ }^{\circ} \mathrm{C}$ ) or the number of months used for SPEI indices.

\begin{tabular}{ccccccc}
\hline \multirow{2}{*}{ Level } & \multicolumn{2}{c}{ Nsir_Tdiff } & \multicolumn{2}{c}{ Nsir_Tmax } & \multicolumn{2}{c}{ SPEI } \\
\cline { 2 - 6 } & Correlation & Synchrony & Correlation & Synchrony & Correlation & Synchrony \\
\hline 1 & $0.18^{\mathrm{ns}}$ & $0.22^{\mathrm{ns}}$ & $0.13^{\mathrm{ns}}$ & $0.15^{\mathrm{ns}}$ & $0.043^{\mathrm{ns}}$ & $0.13^{\mathrm{ns}}$ \\
2 & $0.18^{\mathrm{ns}}$ & $0.22^{\mathrm{ns}}$ & $0.20^{\mathrm{ns}}$ & $0.18^{\mathrm{ns}}$ & $-0.12^{\mathrm{ns}}$ & $0.27^{\mathrm{ns}}$ \\
3 & $0.27^{\circ}$ & $0.23^{\mathrm{ns}}$ & $0.26^{*}$ & $0.15^{\mathrm{ns}}$ & $-0.13^{\mathrm{ns}}$ & $0.36^{\circ}$ \\
4 & $0.27^{\circ}$ & $0.24^{\mathrm{ns}}$ & $0.30^{*}$ & $0.24^{\mathrm{ns}}$ & $-0.15^{\mathrm{ns}}$ & $0.26^{\mathrm{ns}}$ \\
5 & $0.21^{\circ}$ & $0.41^{\circ}$ & $0.32^{\circ}$ & $0.24^{\mathrm{ns}}$ & $-0.17^{\mathrm{ns}}$ & $0.21^{\mathrm{ns}}$ \\
6 & $0.24^{\circ}$ & $0.31^{\mathrm{ns}}$ & $0.31^{*}$ & $0.24^{\mathrm{ns}}$ & $-0.16^{\mathrm{ns}}$ & $0.26^{\mathrm{ns}}$ \\
7 & $0.40^{* *}$ & $0.38^{\circ}$ & $0.44^{* *}$ & $0.45^{*}$ & $-0.16^{\mathrm{ns}}$ & $0.25^{\mathrm{ns}}$ \\
\hline
\end{tabular}

\footnotetext{
${ }^{1}$ Signif. Codes for $p$ values: 0 as ${ }^{* * * \prime}, 0.001$ as ${ }^{\star * * \prime}, 0.01$ as ${ }^{\star * \prime}, 0.05$ as ${ }^{\prime \prime \prime}, 0.1$ as '. ', and 1 as 'ns".
} 


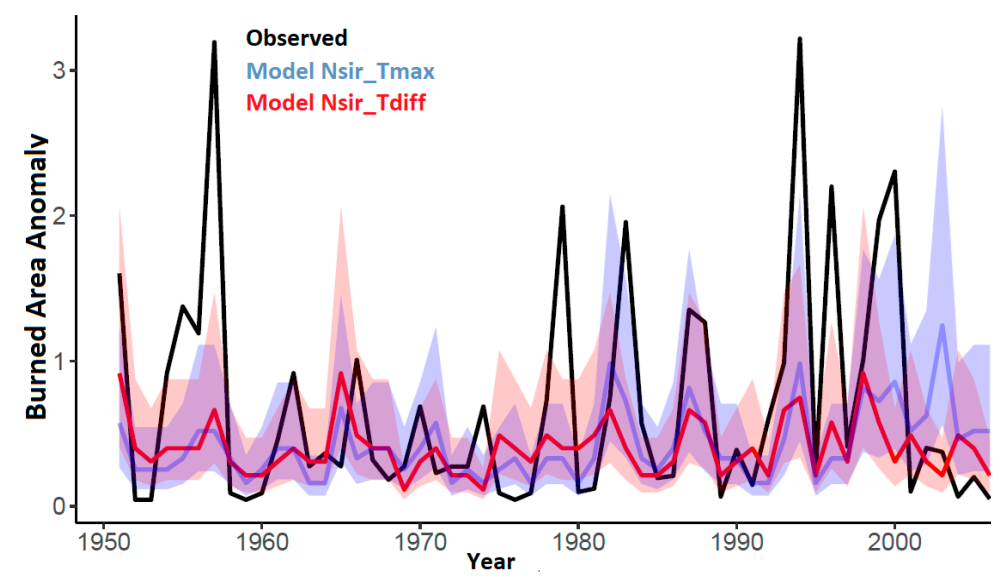

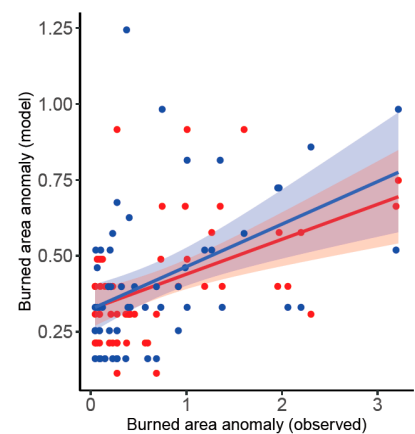

(b)

(a)

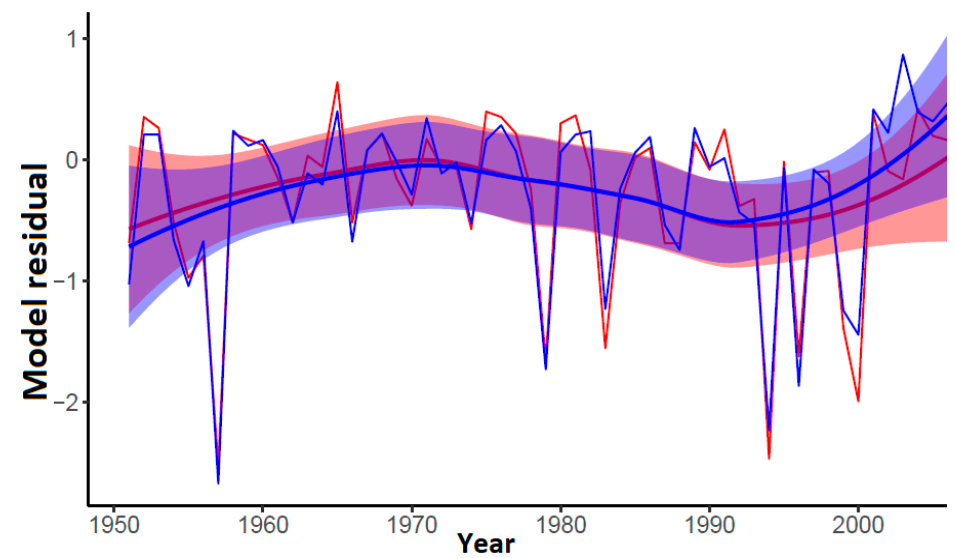

(c)

Figure 5. (a) Yearly burned area anomaly from 1950 to 2006 from observed data (black line) and simulated with the number of Sirocco events based on temperature anomaly (Nsir_Tdiff red line) and temperature threshold (Nsir_Tmax blue line). Shaded areas correspond to the uncertainty. (b). Correlations between observed and simulated burned area anomalies for the temperature anomaly (red dots) and temperature threshold (blue dots) (c) Yearly model residuals with a temporal locally weighted least square regression and 0.9 confidence interval (shaded areas) calculated frim 'loess' option in the ggplot2 'geom_smooth' function.

\section{Discussion}

\subsection{Heat Waves and Fire Events in the Mediterranean Basin}

The results showed that anomalous dry and hot days significantly promoted large fire occurrence in Tunisia and these fires preferentially happened during the dry season under the driest conditions. Dry conditions were necessary for fires to happen, but not sufficient, as they had to be associated with combined dry and hot daily conditions. In Tunisia, fuel moisture conditions can be regionally variable in the forested wettest northern part of the country according to the climate gradient and topographical features $[21,30,31]$. In addition, shallow-rooted shrubland species and the herbaceous litter fuel at the surface layer comprise a large part of natural vegetation, and may be even more susceptible to frequent summer droughts [22,23,32]. Over the whole country, long-term drought reconstructions that are based on tree-rings revealed that recent decades appear as among the driest [33], and confirmed recurrent droughts in the studied period. 
This study, which was the first one on the southern part of the Mediterranean basin, also confirmed previous studies performed in the European Mediterranean region, where annual burned area in the southernmost regions was least correlated to drought inter-annual variability [10]. In these regions, heat waves may be the most important climate-related feature for fire hazard. In Spain, for example, heatwaves have been the strongest drivers of fire occurrence in recent decades [34-36], as well as in Sardinia [37]. Extreme recent fire events in Portugal [38] and Greece [39] were also associated with heatwaves, as was southern France during the exceptional 2003 heat wave [40].

The plant ecophysiology underlying the important influence of heat waves on fire hazard could be leaf temperature and high evaporative demand desiccating leaves and low air humidity increasing heat transfer and decreasing energy used for water vaporization [41]. Recent studies illustrated a decoupling between photosynthesis and transpiration during heatwaves in order to maintain enough transpiration for thermal cooling, to keep leaf temperature below the limits for maintaining physiological functions at the expense of higher leaf desiccation [42]. Further studies should investigate plant functioning during heat waves under dry conditions in the Mediterranean to refine drought-driven fire weather indices.

\subsection{Synoptic Conditions Associated to Sirocco Events and Climate Projections}

In Tunisia and North Africa as a whole, hot and dry weather has been mostly associated with northward winds coming from Sahara $[43,44]$. This weather condition is called Sirocco and it is a recurrent regional atmospheric phenomenon that highly affects agriculture [45] and air quality with subsequent consequences on health and human activities [17,46-48] and regional climate [49].

Meteorological characteristics of Sirocco events in Tunisia have been fully described as mostly occurring between May and August, during the dry season [45]. With an average of 13.3 Sirocco events per year between 1970 and 2004, they are subject to high inter-annual variability, from four events in 2004 to 33 events in 1994 in the city of Sfax (central eastern coast of Tunisia). Sirocco events are associated with slightly faster winds, low air humidity below $20 \%$, and an increased maximum temperature of up to $7^{\circ} \mathrm{C}$, while nighttime minimum temperatures are similar to non-Sirocco days. Overall, these conditions lead to almost a doubling in potential evapotranspiration rate from $5-7 \mathrm{~mm} \cdot \mathrm{day}^{-1}$ to $10-11 \mathrm{~mm} \cdot \mathrm{day}^{-1}$ during Sirocco events. The duration of a Sirocco event can be short day-long events ( $60 \%$ of cases), but can also last from two to six days, particularly during the dry season. Our results are in full agreement with these observations, both regarding the frequency and intensity of the weather anomalies. The Sirocco climatological phenomenon has been described as resulting from three major atmospheric circulation types [45]: (i) when a depression occurs west of the Mediterranean basin and an anticyclone is found east (or either conditions separately) and leads to a northward wind corridor over Tunisia, (ii) when an anticyclonic situation occurs on the southeastern part of Tunisia and generates northward wind towards the depression in the northern part of the country, and (iii) when a depression circulates from west to east on the coastal area of North Africa. All of these situations bring dried and heated air passing over the Sahara desert toward the coastal northern part of Africa [43-45]. This Mediterranean coastal fringe of North Africa adapted to mild temperatures is then particularly highly susceptible to these unusual atmospheric conditions due to its geographic position at the front of these arid regions. The northern part of the Mediterranean basin is less affected by Sirocco winds bringing hot and dry conditions, because air humidity increases and temperature decreases when crossing the Mediterranean Sea. However, western Sirocco events crossing the Mediterranean sea through continental Spain keep their most extreme dry and hot conditions over southern Europe, as evidenced by the recent heatwaves in 2018 and 2019 [50]. General circulation analysis related to Sirocco events illustrates its link to the Northern Atlantic Oscillation (NAO) $[51,52]$ as a synoptic index. 
The synoptic conditions observed in North Africa during Sirocco events are actually very similar to the Santa Ana winds in California [18]. Continental dry and hot winds coming from inland desert blow over the coastal Mediterranean California and lead to extreme fire events [19,53-55]. Similarly, southeastward winds coming from the central Australian desert highly influence southwestern Australia's Mediterranean climate, leading to similar dry and hot conditions, enhanced by Foehn desiccating effect when crossing the Australian Alps [56-58]. These conditions lead to the recent major fire events affecting the country. A similar influence of inland dry and hot winds on fire hazard was observed in the Mediterranean ecosystems of central and south central Chile [59], thus confirming the global propensity of Mediterranean ecosystems bordering hot and dry arid areas to be highly influenced by these dry heat waves.

In turn, most Mediterranean regions worldwide may be highly susceptible to arid weather conditions suddenly blowing over these ecosystems due to their situation at the interface between temperate and arid climates. The climate change-induced heat waves, demonstrated to be overall affected by global warming, may however be moderated or enhanced by local processes [60]. These local processes can lead to contrasted feedbacks, as a reduction in Santa Ana winds in California [61,62], or an increase, as in Australia [63]. Earth system models used in the fifth model intercomparison project (CMIP5) predict that heatwave amplitude, a proxy of heatwave intensity, will increase in the Mediterranean basin [13,64-67], but the frequency of short term Sirocco events has been poorly investigated. Wind fields in climate models also remain an uncertain variable [68].

\subsection{Future Relevant Indices for Fire Hazard Assessment and Modelling}

Fire hazard in the Mediterranean basin and worldwide is mostly assessed through the Fire Weather Index, which combines drought, temperature, wind velocity, and air humidity, so that global and regional fire hazard trends are mostly based on this index [14,69-71]. The drought component has been shown to properly describe the drought season through the fuel moisture status critical for allowing fire ignition and spread [26], and investigated from field measurements [72] and remote sensing [21]. This index has been discussed and modified for the Mediterranean area [73]. A similar approach combining an empirical drought code with weather variables is used in the fire modules of global dynamic vegetation models [74,75]. However, recent studies have also shown the potential regional [76] or temporal [38] variability in the relative contribution of each meteorological variable to properly model actual fire hazard due to changes in land cover, firefighting strategies, or anthropogenic factors. With no aerial intervention plans and only recently settled fire stations, Tunisia can be considered as much less equipped than European countries for fighting fires, so that all fire-prone climate conditions can actively contribute to fire hazard. European countries have increasingly managed to prevent large fires under non-windy conditions [40]. In turn, fire hazard models that are designed for Europe might fail on the southern shore of the Mediterranean basin. Here, our results showed that, in addition to recurrent drought with low inter-annual variability, heat waves during Sirocco events (that associate hot, dry, and windy conditions) were the most favorable conditions for large fires. The fire size was proportional to the duration of this event, as reported in California during Santa Ana events [53] and in the Mediterranean basin [15]. We concluded with a strong correlation between the timeframe of fire spread and the persistence of the fire-prone synoptic conditions.

The Hot-Dry-Windy (HDW) index has recently been developed and tested in the USA to better capture climate features that are associated with large fire events $[77,78]$ as a combination of surface and high atmosphere synoptic and meso-alpha-scale conditions contribution to dangerous fire behavior, when compared to other indices. Local scale indices for early warning fire danger or fire hazard modelling could be developed for North Africa based on simple Sirocco events predictions. In our results, temperature alone can be misleading. Increasing temperature in the region did not lead to increasing fire activity 
in the last decade, but the extreme maximum temperature increases fairly captured Sirocco events and the subsequent burned area in Tunisia. Such events should also drive inter-annual variability in neighboring countries, such as Algeria [79] and Morocco [80], as well as Middle East countries [81,82] with similar arid/Mediterranean interface.

\section{Conclusions}

The regional effect of Saharan Sirocco events was shown to strongly influence the inter-annual variability of burned area in Tunisia. These atmospheric circulation events lead to a northward hot and dry wind coming from Sahara desert, modifying for three to 10 days the current weather, already hot and dry during the summer fire-prone season in the region. However, the increasing mean temperature in the last three decades did not lead to increasing burned area, so that fire hazard was more related to the number of yearly Sirocco events defined by short temporal scale anomalies in temperatures and air humidity than absolute temperature itself. In turn, Sirocco events in future climate projections should be better quantified with a standard index for their efficient characterization. Fire hazard modelling that is based on absolute temperature, such as the Fire Weather Index, should be evaluated in this region, as it might overestimate projected fire hazard and burned area. Further studies should also be devoted to plant functioning for desiccation processes during these particular events, and the subsequent impact on combustion processes.

Author Contributions: C.B.-K., T.E.-M. and F.M. jointly conceived the study. T.E.-M. provided climate information and analysis, C.B.-K. provided fire data and analyzed the data, and F.M. performed the statistical analysis. F.M. and C.B.-K. wrote the manuscript. T.E.-M. and F.M. jointly supervised C.B.-K. as a PhD student. All authors have read and agreed to the published version of the manuscript.

Funding: This research was funded by EU FP7 FUME project, contract grant $\mathrm{N}^{\circ} 243888$ and French observatory for Mediterranean environment OSU “OREME".

Acknowledgments: We thank Samir Belhadj Salah (Direction Générale des Forêts, DGDF Tunis, Tunisia) for providing access to the Tunisian forest fire database and his expert knowledge on fire hazard in Tunisia. We also thank Catherine Airey-Lauvaux for English revisions.

Conflicts of Interest: The authors declare no conflict of interest.

\section{References}

1. Mouillot, F.; Ratte, J.P.; Joffre, R.; Mouillot, D.; Rambal, S. Long term forest dynamic after land abandonment in a fire prone Mediterranean landscape. Landsc. Ecol. 2005, 20, 101-112. [CrossRef]

2. Viedma, O. The influence of topography and fire in controlling landscape composition and structure in Sierra de Gredos (Central Spain). Landsc. Ecol. 2008, 23, 657-672. [CrossRef]

3. Keeley, J.E.; Pausas, J.G.; Rundel, P.W.; Bond, W.J.; Bradstock, R.A. Fire as an evolutionary pressure shaping plant traits. Trends Plant Sci. 2011, 26, 406-411. [CrossRef] [PubMed]

4. Krawchuck, M.A.; Moritz, M.A. Constraints on global fire activity vary across a resource gradient. Ecology 2011, 92, 121-132. [CrossRef] [PubMed]

5. Loepfe, L.; Rodrigo, A.; Lloret, F. Two thresholds determine climatic control of forest fire size in Europe and northern Africa. Reg. Environ. Chang. 2014, 14, 1395-1404. [CrossRef]

6. Pausas, J.G.; Paula, S. Fuel shapes the fire-climate relationship: Evidence from Mediterranean ecosystems. Glob. Ecol. 2012, 21, 1074-1082. [CrossRef]

7. Urbieta, I.R.; Zavala, G.; Bedia, J.; Gutierrez, J.M.; San Miguel-Ayanz, J.; Camia, A.; Keeley, J.E.; Moreno, J.M. Fire activity as a function of fire weather seasonal severity and antecedent climate across spatial scales in southern Europe and Pacific Western USA. Environ. Res. Lett. 2015, 10, 11403. [CrossRef]

8. Xystrakis, F.; Kallimanis, A.S.; Dimopoulos, P.; Halley, J.M.; Koutsias, N. Precipitation dominates fire occurrence in Greece (1900-2010): Its dual role in fuel build-up and dryness. Nat. Hazards Earth Syst. 2014, 14, 21-32. [CrossRef] 
9. Gudmundson, L.; Rego, F.C.; Rocha, M.; Seneviratne, S.I. Predicting above normal wildfire activity in southern Europe as a function of meteorological drought. Environ. Res. Lett. 2014, 9, 084008. [CrossRef]

10. Turco, M.; von Hardenberg, J.; Aghakouchak, A.; Llasat, M.C.; Provenzale, A.; Trigo, R.M. On the key role of droughts in the dynamics of summer fires on Mediterranean Europe. Sci. Rep. 2017, 7, 81. [CrossRef] [PubMed]

11. Lehmann, C.E.R.; Anderson, T.M.; Sankaran, M.; Higgins, S.I.; Archibald, S.; Hoffmann, W.A.; Hanan, N.P.; Williams, R.J.; Fensham, R.J.; Felfili, J.; et al. Savanna vegetation-fire-climate relationships differ among continents. Science 2014, 343, 548-552. [CrossRef] [PubMed]

12. Parks, S.A.; Parisien, M.A.; Miller, C. Spatial bottom-up controls on fire likelihood vary across western North America. Ecosphere 2012, 3, 1-20. [CrossRef]

13. Cardil, A.; Molina, D.M.; Kobziar, L.N. Extreme temperature days and their potential impacts on southern Europe. Nat. Hazards Earth Syst. 2014, 14, 3005-3014. [CrossRef]

14. Moriondo, M.; Good, P.; Durao, R.; Bindi, M.; Giannakopoulos, C.; Corte-Real, J. Potential impact of climate change on fire risk in the Mediterranean area. Clim. Res. 2006, 31, 85-95. [CrossRef]

15. Hernandez, C.; Drobinski, P.; Turquety, S. How much does weather control fire size and intensity in the Mediterranean region? Ann. Geophys. 2012, 33, 931-939. [CrossRef]

16. Ruffault, J.; Moron, V.; Trigo, R.M.; Curt, T. Objective identification of multiple large fire climatologies and application to a Mediterranean ecosystem. Environ. Res. Lett. 2016, 11, 075006. [CrossRef]

17. Azri, C.; Abida, H.; Medhioub, K. Geochemical behavior of the Tunisian background aerosols in sirocco wind circulations. Adv. Atmos. Sci. 2016, 26, 390-402. [CrossRef]

18. Abatzoglou, J.T.; Barbero, R.; Nauslar, N.J. Diagnosis Santa Ana winds in southern California with synoptic-scale analysis. Weather Forecast. 2013, 28, 704-710. [CrossRef]

19. Jin, Y.F.; Goulden, M.L.; Faivre, N.; Veraverbeke, S.; Sun, F.P.; Hall, A.; Hand, M.S.; Hook, S.; Randerson, J.T. Identification of two distinct fire regimes in southern California: Implications for economic impact and future change. Environ. Res. Lett. 2015, 10, 094005. [CrossRef]

20. Belhadj-Khedher, C.; Koutsias, N.; Karamitsou, A.; El-Melki, T.; Ouelhazi, B.; Hamdi, A.; Nouri, H.; Mouillot, F. A revised historical fire regime analysis in Tunisia (1985-2010) from a critical analysis of the national fire database and remote sensing. Forests 2018, 9, 59. [CrossRef]

21. Chakroun, H.; Mouillot, F.; Hamdi, A. Regional equivalent water thickness modeling from remote sensing across a tree cover/LAI gradient in Mediterranean forests of Northern Tunisia. Remote Sens. 2015, 7, $1937-1961$. [CrossRef]

22. Rezgui, F.; Gharbi, F.; Zribi, L.; Mouillot, F.; Ourcival, J.M.; Hanchi, B. Soil respiration behavior in a Mediterranean Aleppo pine forest in north Tunisia. Appl. Ecol. Environ. Res. 2016, 14, 343-356. [CrossRef]

23. Longepierre, D.; Mouillot, F.; Ouelhazi, B.; Ourcival, J.M.; Rocheteau, A.; Degueldre, D.; Rejeb, M.N. True water constraint under a rainfall interception experiment in a =Mediterranean shrubland (Northern Tunisia): Confronting discrete measurements with a plant soil water budget model. Plant Ecol. 2014, 215, 779-794. [CrossRef]

24. Giglio, L.; Schroeder, W.; Justice, C.O. The collection 6 MODIS active fire detection algorithm and fire product. Remote Sens. Environ. 2016, 178, 31-41. [CrossRef] [PubMed]

25. Fosberg, M.A. Weather in wildland fire management: The fire weather index. In Proceedings of the Conference on Sierra Nevada Meterology, Lake Tahoe, CA, USA, 19-21 June 1978; pp. 1-4.

26. Pelizzaro, G.; Cesaraccio, C.; Duce, P.; Ventura, A.; Zara, P. Relationships between seasonal patterns of live fuel moisture and meterological drought indices for Mediterranean shrubland species. Int. J. Wildl. Fire 2007, 26, 232-241. [CrossRef]

27. Beguería, S.; Vicente-Serrano, S.M.; Angulo, M. A multi-scalar global drought data set: The SPEIbase: A new gridded product for the analysis of drought variability and impacts. Bull. Am. Meteorol. Soc. 2010, 91, 1351-1354. [CrossRef]

28. Royston, P. An extension of Shapiro and Wilk's W test for normality to large samples. J. R. Stat. Soc. C Appl. 1982, 31, 115-124. [CrossRef] 
29. Gouhier, T.C.; Guichard, F. Synchrony: Quantifying variability in space and time. Methods Ecol. Evol. 2014, 5, 524-533. [CrossRef]

30. Zribi, L.; Mouillot, F.; Guibal, F.; Rejeb, S.; Rejeb, M.N.; Gharbi, F. Deep soil conditions make Mediterranean coirk oak stem growth vulnerable to autumnal rainfall decline in Tunisia. Forests 2016, 7, 245. [CrossRef]

31. Chakroun, H.; Mouillot, F.; Nasr, Z.; Nouri, M.; Ennajah, A.; Ourcival, J.M. Performance of LAI-MODIS and the influence on drought simulation in a Mediterranean forest. Ecohydrology 2014, 7, 1014-1028. [CrossRef]

32. Zribi, L.; Mouillot, F.; Gharbi, F.; Ourcival, J.M.; Hanchi, B. Warm and fertile sub humid conditions enhance litterfall to sustain high soil respiration fluxes in a Mediterranean cork oak forest. Forests 2015, 6, 2918-2940. [CrossRef]

33. Touchan, R.; Anchukaitis, K.J.; Meko, D.M.; Sabir, M.; Attalah, S.; Aloui, A. Spatiotemporal drought variability in northwestern Africa over the last nine centuries. Clim. Dyn. 2011, 37, 237-252. [CrossRef]

34. Cardil, A.; Eastaugh, C.S.; Molina, D.M. Extreme temperature conditions and wildland fires in Spain. Theor. Appl. Clim. 2011, 122, 219-228. [CrossRef]

35. Cardil, A.; Merenciano, D.; Molina-Terren, D.M. Wildland fire typologies and extreme temperatures in NE Spain. IForest 2017, 10, 9-14. [CrossRef]

36. Molina-Terren, D.M.; Cardil, A. Temperature determining larger wildland fires in NE Spain. Theor. Appl. Clim. 2016, 125, 295-302. [CrossRef]

37. Cardil, A.; Salis, M.; Spano, D.; Delogu, G.; Terren, D.M. Large wildland fires and extreme temperatures in Sardinia (Italy). IForest 2014, 7, 162-169. [CrossRef]

38. Pereira, M.G.; Trigo, R.M.; da Camara, C.C.; Pereira, J.M.C.; Leite, S.M. Synoptic patterns associated with large summer forest fires in Portugal. Agric. For. Meteorol. 2005, 129, 11-25. [CrossRef]

39. Lagouvardos, K.; Kotroni, V.; Giannaros, T.M.; Dafis, S. Meteorological conditions conducive to the rapid spread of the deadly wildfire in eastern Attica, Greece. Bull. Am. Meterol. Soc. 2019, 18, 0231. [CrossRef]

40. Ruffault, J.; Mouillot, F. How a new fire suppression policy can abruptly reshape the fire-weather relationship. Ecosphere 2015, 6, 1-19. [CrossRef]

41. Montaldo, N.; Oren, R. The way the wind blows matters to ecosystem water use efficiency. Agric. For. Meteorol. 2016, 217, 1-9. [CrossRef]

42. Drake, J.E.; Tjoelker, M.G.; Varhammar, A.; Medlyn, B.E.; Reich, P.B.; Lgih, A.; Pfaitsch, S.; Blackman, C.J.; Lopez, R.; Aspinwall, M.J.; et al. Trees tolerate an extreme heatwave via sustained transpirational cooling and increased leaf thermal tolerance. Glob. Chang. Biol. 2018, 24, 2390-2402. [CrossRef] [PubMed]

43. Henia, L. Le sirocco et les types de temps à Sirocco en Tunisie. Revue Tunisiennne Géographie 1980, 5, 61-87.

44. Traboulsi, M.; Ben Boubaker, H. High heat and associated atmospheric circulation around the Mediterranean: Case of the Tunisian and Syrian-lebanese coasts. Territoire Movement Revue Géographie Aménagement 2012, 14-15, 106-119. [CrossRef]

45. Dahech, S.; Beltrando, G.; Henia, L. Le sirocco et son impact sur l'agriculture et la qualité de l'air dans la region de Sfax (Tunisie). Sécheresse 2007, 18, 177-184.

46. Dammark, R.; Bahloul, M.; Chabbi, I.; Azri, C. Spatial and temporal variations of dust particle deposition at three "urban/suburban" areas in Sfax city (Tunisia). Environ. Monitor. Assess. 2016, 188, 336. [CrossRef] [PubMed]

47. Ellouz, F.; Masmoudi, M.; Medhioub, K.; Azri, C. Temporal evolution and particle size distribution of aerosol constituents collected in Northern Tunisia (Boukornine) under sirocco wind circulations. Arab. J. Geosci. 2014, 7 , 4399-4406. [CrossRef]

48. Trabelsi, A.; Masmoudi, M. An investigation of atmospheric turbidity over the Kerkennah island in Tunisia. Atmos. Res. 2011, 101, 22-30. [CrossRef]

49. Suman, D.O. Biomass burning in North Africa and its possible relationship to climate change in the Mediterranean basin. In Impact of Desert Dust Across the Mediterranean; Guerzoni, S., Cjhester, R., Eds.; Springer: Dordrecht, The Netherlands, 1996; Volume 11, pp. 113-122.

50. Sousa, P.M.; Barriopedro, D.; Ramos, A.M.; Garcia-Herrera, R.; Espirito-Santo, F.; Trigo, R.M. Saharan air intrusion as a relevant mechanism for Iberian heatwaves: The record breaking events of August 2018 and June 2019. Weather Clim. Extremes 2019, 26, 100224. [CrossRef] 
51. Lionello, P.; Sanna, A. Mediterranean wave climate variability and its link with NAO and indian Monsoon. Clim. Dyn. 2005, 25, 611-623. [CrossRef]

52. Conte, M.; Colacino, M.; Piervitali, E. Atlantic disturbances deeply penetrating the African continent: Effects over Saharan regions and the Mediterranean Basin. In Impact of Desert Dust Across the Mediterranean; Guerzoni, S., Chester, R., Eds.; Springer: Dordrecht, The Netherlands, 1996; Volume 11, pp. 93-102.

53. Billmire, M.; French, N.H.F.; Loboda, T.; Owen, R.C.; Tyner, M. Santa Ana winds and predictors of wildfire progression in southern California. Int. J. Wildl. Fire 2014, 23, 1119-1129. [CrossRef]

54. Moritz, M.A.; Moody, T.J.; Krawchuk, M.A.; Hughes, M.; Hall, A. Spatial variation in extreme winds predicts large wildfire locations in chaparral ecosystems. Geophys. Res. Lett. 2010, 37, L04801. [CrossRef]

55. Kolden, C.A.; Abatzoglou, J.T. Spatial distribution of wildfires ignited under katabatic versus non-katabatic winds in Mediterranean southern California USA. Fire 2018, 1, 19. [CrossRef]

56. Sharples, J.J.; Mills, G.A.; McRae, R.H.D.; Weber, R.O. Foehn-like winds and elevated fire danger conditions in southeastern Australia. J. Appl. Meteorol. Climatol. 2010, 49, 1067-1095. [CrossRef]

57. Fox-Hughes, P. Characteristics of some days involving abrupt increases in fire danger. J. Appl. Meteorol. Climatol. 2015, 54, 2353-2363. [CrossRef]

58. Engel, C.B.; Lane, T.P.; Reeder, M.J.; Rezny, M. The meteorology of black Saturday. Q. J. R. Meterol. Soc. 2013, 139, 585-599. [CrossRef]

59. Urrutia-Jalabert, R.; Gonzalez, M.E.; Gonzalez-Reyes, A.; Lara, A.; Garreaud, R. Climate variability and forest fires in central and south-central Chile. Ecosphere 2018, 9, e02171. [CrossRef]

60. Baldi, M.; Dalu, G.; Maracchi, G.; Pasui, M.; Cesarone, F. Heat waves in the Mediterranean: A local feature or a larger scale effect? Int. J. Climatol. 2006, 26, 1477-1487. [CrossRef]

61. Guzman-Morales, J.; Gershunov, A. Climate change suppresses Santa Ana winds of southern California and sharpens their seasonality. Geophys. Res. Lett. 2019, 46, 2772-2780. [CrossRef]

62. Miller, N.L.; Schlegel, N.J. Climate change projected fire weather sensitivity: California Santa Ana wind occurrence. Geophys. Res Lett. 2006, 33, L15711. [CrossRef]

63. Dowdy, A.J.; Ye, H.; Pepler, A.; Thatcher, M.; Osbrough, S.L.; Evans, J.P.; di Virgilio, G.; Mc Carthy, N. Future changes in extreme weather and pyroconvection risk factors for Australian wildfires. Sci. Rep. 2019, 9, 10073. [CrossRef] [PubMed]

64. Ouzeau, G.; Soubeyroux, J.M.; Schneider, M.; Vautard, R.; Planton, S. Heat waves analysis over France in present and future climate: Application of the new method on the EURO CORDEX ensemble. Clim. Serv. 2016, 4, 1-12. [CrossRef]

65. Dosio, A.; Mentaschi, L.; Fischer, E.M.; Wyser, K. Extreme heat waves under $1.5^{\circ} \mathrm{C}$ and $2{ }^{\circ} \mathrm{C}$ global warning. Environ. Res. Lett. 2018, 13, 054006. [CrossRef]

66. Diffenbaugh, N.S.; Pal, J.S.; Giorgi, F.; Gao, X. Heat stress intensification in the Mediterranean climate change hotspot. Geophys. Res. Lett. 2007, 34, L11706. [CrossRef]

67. Lelieveld, J.; Proestos, Y.; Hadjinicolaou, P.; Tanarhte, M.; Tyrlis, E.; Zittis, G. Strongly increasing heat extremes in the middle East and North Africa (MENA) in the 21rst century. Clim. Chang. 2016, 137, 245-260. [CrossRef]

68. Vozila, A.B.; Guttler, I.; Ahrens, B.; Obermann-Hellhund, A.; Prtenjak, M.T. Wind over the Adriactic region in CORDEX climate change scenarios. J. Geophys. Res. Atmos. 2019, 124, 110-130. [CrossRef]

69. Jolly, W.M.; Cochrane, M.A.; Freebirn, P.H.; Holden, Z.A.; Brown, T.J.; Williamson, G.J.; Bowman, D.M.J.S. Climate induced variations in global wildfire danger from 1979 to 2013. Nat. Commun. 2019, 6, 7537. [CrossRef] [PubMed]

70. Field, R.D.; Spessa, A.C.; Aziz, N.A.; Camia, A.; Cantin, A.; Carr, R.; de Groot, W.J.; Dowdy, A.J.; Flannigan, M.D.; Manomaiphiboon, K.; et al. Development of a global fire weather database. Nat. Hazards Earth Syst. Sci. 2019, 15, 1407-1423. [CrossRef]

71. Turco, M.; Rosa-Canovas, J.J.; Bedia, J.; Jerez, S.; Montavez, J.P.; Llasat, M.C.; Provenzale, A. Exacerbated fires in Mediterranean Europe due to anthropogenic warming projected with non-stationary climate fire models. Nat. Commun. 2018, 9, 3821. [CrossRef] [PubMed] 
72. Yebra, M.; Scortechini, G.; Badi, A.; Beget, M.E.; Boer, M.; Bradstock, R.; Chuvieco, E.; Danson, F.M.; Dennison, P.; de Dios, V.R.; et al. Globe-LFMC, a global plant water status database for vegetation ecophysiology and wildfire applications. Sci. Data 2019, 6, 155. [CrossRef] [PubMed]

73. Chelli, S.; Maponi, P.; Campetella, G.; Monteverde, P.; Foglia, M.; Paris, E.; Lolis, A.; Panagopoulos, T. Adaptation of the Canadian fire weather index to Mediterranean forests. Nat. Hazards 2015, 75, 1795-1810. [CrossRef]

74. Hantson, S.; Arneth, A.; Harrison, S.P.; Kelley, D.I.; Prentice, I.C.; Rabin, S.S.; Archibald, S.; Mouillot, F.; Arnold, S.R.; Artaxo, P.; et al. The Status and challenges of global fire modelling. Biogeosciences 2016, 13, 3359-3375. [CrossRef]

75. Rabin, S.S.; Meton, J.R.; Lasslop, G.; Bachelet, D.; Forrest, M.; Hantson, S.; Kaplan, J.O.; Li, F.; Mangeon, S.; Ward, D.S.; et al. The fire modelling intercomparison project (FIREMIP), phase 1: Experimental and analytical protocols with detailed model descriptions. Geosci. Model Dev. 2017, 10, 1175-1197. [CrossRef]

76. Amatulli, G.; Camia, A.; San Miguel-Ayanz, J. Estimating future burned areas under changing climate in the EU-Mediterranean countries. Sci. Total Environ. 2013, 450, 209-222. [CrossRef] [PubMed]

77. Mc Donald, J.M.; Srock, A.F.; Charney, J.J. Development and application of a hot-dry-windy index (HDW) climatology. Atmosphere 2018, 9, 285. [CrossRef]

78. Srock, A.F.; Charney, J.J.; Potter, B.E.; Goodrick, S.L. The Hot-Dry-Windy index: A new fire weather index. Atmosphere 2018, 9, 279. [CrossRef]

79. Meddour-Sahar, O. Wildfires in Algeria: Problems and challenges. IForest 2015, 8, 818-826. [CrossRef]

80. Chergui, B.; Fahd, S.; Santos, X.; Pausas, J.G. Socio economic factors drive fire regime variability in the Mediterranean basin. Ecosystems 2015, 21, 619-628. [CrossRef]

81. Mitri, G.; Saba, S.; Nader, M.; McWethy, D. Developing Lebanon's fire danger forecast. Int. J. Disaster Risk Res. 2017, 24, 332-339. [CrossRef]

82. Turco, M.; Levin, N.; Tessler, N.; Saaroni, H. Recent changes and relations among drought, vegetation and wildfires in the Eastern Mediterranean: The case of Israel. Glob. Planet. Chang. 2017, 151, 28-35. [CrossRef]

(C) 2020 by the authors. Licensee MDPI, Basel, Switzerland. This article is an open access article distributed under the terms and conditions of the Creative Commons Attribution (CC BY) license (http://creativecommons.org/licenses/by/4.0/). 